\title{
THE
}

\section{Assessing Invasive Alien Species Across Multiple Spatial Scales: Working Globally and Locally}

Laura A. Meyerson

University of Rhode Island, lameyerson@uri.edu

Richard N. Mack

Betsy Von Holle

Follow this and additional works at: https://digitalcommons.uri.edu/nrs_facpubs

Terms of Use

All rights reserved under copyright.

\section{Citation/Publisher Attribution}

Mack R.N., Von Holle B., Meyerson L.A. (2007) Assessing invasive alien species across multiple spatial scales: working globally and locally. Front. Ecol. Environ., 5:217-220.

Available at: http://dx.doi.org/10.1890/1540-9295(2007)5[217:AIASAM]2.0.C0;2

This Article is brought to you for free and open access by the Natural Resources Science at DigitalCommons@URI. It has been accepted for inclusion in Natural Resources Science Faculty Publications by an authorized administrator of DigitalCommons@URI. For more information, please contact digitalcommons-group@uri.edu. 


\section{ECOLOGICAL SOCIETY OF AMERICA}

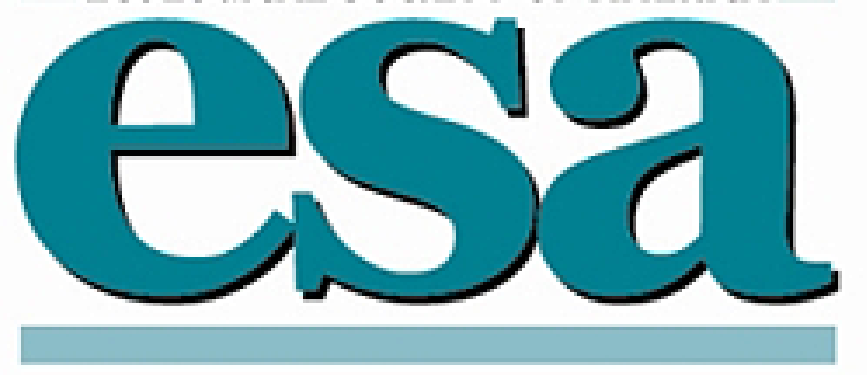

Assessing Invasive Alien Species across Multiple Spatial Scales: Working Globally and Locally Author(s): Richard N. Mack, Betsy Von Holle and Laura A. Meyerson

Source: Frontiers in Ecology and the Environment, Vol. 5, No. 4, Ecology in an Era of Globalization (May, 2007), pp. 217-220

Published by: Ecological Society of America

Stable URL: http://www.jstor.org/stable/20440625

Accessed: $12 / 07 / 2013$ 14:28

Your use of the JSTOR archive indicates your acceptance of the Terms \& Conditions of Use, available at http://www.jstor.org/page/info/about/policies/terms.jsp

JSTOR is a not-for-profit service that helps scholars, researchers, and students discover, use, and build upon a wide range of content in a trusted digital archive. We use information technology and tools to increase productivity and facilitate new forms of scholarship. For more information about JSTOR, please contact support@jstor.org. 


\title{
Assessing invasive alien species across multiple spatial scales: working globally and locally
}

\author{
Richard N Mack ${ }^{1 *}$, Betsy Von Holle ${ }^{2}$, and Laura A Meyerson ${ }^{3}$
}

Quantitative investigations on invasive alien species (IAS) across multiple spatial scales are needed because biological invasions often encompass enormous expanses in both donor and invaded ranges and because the immigrants may be carried great distances between these ranges. Although invasion biology is rich in anecdotes, translation of this information into generalizations remains limited by technical shortcomings in data acquisition, inconsistent data assembly, and the continuing search for meaningful indices of the impact of IAS. Much better justification of and greater opportunities to combat IAS could be achieved by distilling all information for IAS into spatially explicit case histories and synthetic predictions on the epidemiology and consequences of biological invasions for public review, discussion, and action.

Las investigaciones cuantitativas sobre las especies exóticas invasoras (EEI) a través de numerosas escalas espaciales son necesarias porque las invasiones biológicas abarcan a menudo enormes extensiones, tanto en las áreas de distribución originales como en las áreas invadidas, y porque estos inmigrantes pueden ser transportados a través de grandes distancias entre estas áreas. Aunque la biología de las invasiones es rica en anécdotas, la conversión de esta información en generalizaciones todavía está limitada por deficiencias técnicas en la adquisición de los datos, inconsistencias en el ensamblaje de los datos, y la búsqueda continua de índices significativos del impacto de las EEI. Se podría alcanzar una mejor justificación y mejores oportunidades de combatir a las EEI destilando toda la información de las EEI en estudios de caso espacialmente explícitos y predicciones sintéticas sobre la epidemiología y las consecuencias de las invasiones biológicas para la revisión pública, la discusión y la acción.

Front Ecol Environ 2007; 5(4): 217-220

A well-worn adage from the environmental movement is "think globally, act locally". Those concerned with invasive alien species (IAS) do not have the luxury of acting in strict accordance with this phrase. IAS arise through the increasingly frequent movement of species around the planet, as products of international transportation and commerce. These biological invaders cause negative economic (Pimentel et al. 2005) and ecological (Parker et al. 1999) impacts in the regions they infest (Figure 1). Attention to spatial scale becomes essential in understanding and predicting invasions and in minimizing their consequences; the spatial scale at which some IAS operate can be enormous, not only in the new range, but also in the donor range(s).

Workshop: Quantifying the impacts of invasive alien species - what can we learn at the global scale?

Organized by: L Meyerson and O Sala

Ecology in an era of globalization

Ecological Society of America International Conference

Merida, Mexico; 8-12 Jan 2006

http://abstracts.co.allenpress.com/pweb/esai2006/schedule/

Authors' contact details are on $p 220$
Predicting the source or donor locale from which a potential recipient community may receive invasive species means considering broad swaths of the Earth's communities. Even though our local concern may be with identifying which alien species could become invasive in a community, we may need to evaluate species similar to our focal species in physiognomy, distribution of life forms, or functional groups, and residing in communities worldwide. "Similarity" may also lie in gross physical features of the environment (similar climate, soils, or latitude) that support likely donor and recipient communities. Even with this broad-scale view, we are often surprised by unanticipated invaders: species that may play only a minor role in their native communities can proliferate and spread rapidly once carried to a new range. Furthermore, many species have become invasive in environments that differ substantially from their native ranges; examples include Eichhornia crassipes, an aquatic vascular plant native to the Amazon drainage and invasive in subtropical rivers in Florida and even California (Spencer and Kasander 2005), and Sorghum halepense, a grass native to southern Eurasia, and now invasive in much of temperate North America as far north as Ontario (Mack [1996] and references therein).

Furthermore, the great distances and high frequency at 
Figure 1. The invasion of Bromus tectorum (cheatgrass) in the western US illustrates the need to consider effects of an invader at multiple spatial scales. (a) The grass is a dominant weed in wheat fields in the Intermountain West in the absence of diligent herbicide application. (b) Fires, fueled by cheatgrass straw, cause much more damage in the region's enormous rangelands each summer, as shown in this photo, taken in Holbrook, ID in 1946. Once denuded by fire, the barren landscape can easily erode into the Snake and Columbia Rivers.

which organisms are routinely transported means that the connectivity of the Earth's biota has never been greater (eg the likelihood that species from Britain could be carried to New Zealand, where many have subsequently become invasive, would be vanishingly small were it not for the direct and continuous stream of commerce that flows between those widely separated locales). Many new invasions are secondary introductions (Drake and Lodge 2004). For example, a species native to Britain could invade New Zealand via an introduced population in Australia. Finally, great distances have been spanned by species via human-mediated dispersal since antiquity: medieval Vikings may have deliberately transported the edible soft-shell clam, Mya arenaria, from North America to northern Europe (Petersen et al. 1992).

\section{Quantifying invasions across multiple spatial scales}

An invasion typically progresses through three phases: arrival, establishment, and integration into the recipient habitat (Lodge 1993). In any of these phases, the much more common outcome of immigration - local extinction - may arise, because the physical environment in the new range is inclement, the biotic resistance insurmountable, or because some other mechanism prevents invasion. Additionally, the importance of the different elements probably varies at each stage (Lodge 1993). These events unfold at progressively larger spatial scales, demanding different approaches to track them spatially.

Our emphasis here is on events that play out across large spatial scales, but following IAS at the local scale is still necessary. We need different tools to determine the expansion of species in the new range, while at the same time identifying all the occupied communities, in order to better predict which communities the invader may yet enter (Parker et al. 1999). Fortunately, some species (eg aquatic vascular plants, some migratory winged insects, those terrestrial plants with distinctive morphology or phenologic change in color) readily lend themselves to being mapped at a large areal scale through remote sensing (Mack 2005); unfortunately, many others are not so easily detected. Nevertheless, representatives of all taxonomic groupings of IAS need to be followed at the largest scale in the landscape (or waterscape) that they occupy.

This workshop explored the opportunities for, and challenges associated with, quantifying IAS and their impacts at multiple spatial scales, with an emphasis on global collaboration and data collection. Participants from across the Americas debated the following question: what are the benefits and novel results of, and impediments to, taking a spatially expansive approach to quantifying biological invasions?

\section{Tools and procedures}

A growing arsenal of tools are available with which to monitor IAS at multiple scales (global, regional, national, and local), and the dynamic discipline of landscape ecology is specifically directed toward investigating ecological processes across large areas (With 2002). Yet, despite the exciting potential for investigating IAS at all relevant spatial scales, our optimism should be tempered because serious historical and logistical impediments remain:

- Ideally, we need to compile historic records of the spread of invasions. However, these data are not usually available. Even where records exist, they are often collected with different (and irreconcilable) procedures. Even an ecological parameter as seemingly straightforward as "frequency" can unravel into a bewildering array of procedures and tools that were never uniform and have changed over time.

- As indicated above, some species lend themselves to numerical estimates, even by remote sensing; however, 
most do not. Also, while techniques for remote sensing of habitats and organisms will improve, we are unlikely to have the ability to use instruments to assess all species at all spatial scales any time soon (Mack 2005). Laborious field surveys are likely to remain the gold standard for some time to come.

- Equally important to mapping the extent and population sizes of IAS is the need to quantify, with multiple indices, their effect on ecosystems. Assessments of effects on native species in invaded communities have the same limitations as cited above for assessments of IAS. Gauging any changes in the physical environment may be more straightforward, especially if the effect can be measured by remote sensing. Separate indices for biological, economic, and sociocultural assessments will nonetheless be necessary to respond to the scientific and policy issues that arise from IAS (Meyerson et al. in press).

- Even if data collection becomes comprehensive and reliable, the effective organization of these data in formats to which specific queries can be posed could be daunting. Invasion biology is already an anecdote-rich field, underpinned with diverse datasets. Data acquisition must, in the future, be attuned to its eventual role in forming a synthetic understanding of these phenomena. Fortunately, we can draw confidence from the success of conceptually similar undertakings in biology in the last 20 years (eg the Tree of Life Project; http://tolweb.org/tree/phylogeny.html) and the burgeoning efforts to barcode species (http://barcoding.si.edu). Both have successfully integrated large datasets, collected by scores of investigators, on many species. Key to the success of these efforts was the early development of a reliable data collection protocol that was universally implemented.

\section{The pay-off}

For ecologists, the need to investigate IAS at multiple spatial scales is readily apparent; these events usually encompass enormous expanses of potential area from which immigrant species can be drawn, long distances traversed by immigrants to a new range, and much variation in the extent of new ranges eventually occupied by the invasive species' descendants. We seek to quantify these events at all spatial scales, in an effort to understand how and why these fascinating biological phenomena occur. The introduction of non-native species into natural ecosystems has been used to probe classic ecological and evolutionary questions, such as the importance of species and functional group interactions in structuring ecological communities, limits to species diversity, the evolution of reproductive isolation, and the genetic and evolutionary consequences of population bottlenecks (Sax et al. 2005). But these reasons are usually insufficient justification for public investment in quanti-
Figure 2. The scene at the Lower Granite Dam in southeastern Washington State typifies the current regional environment. Vegetation in the landscape surrounding the dam, including the valley walls, is almost totally dominated by cheatgrass (both immature green plants on the opposite valley wall and mature pinkish-brown plants on most slopes, including those in the foreground). Erosion from these surfaces after the invasion of cheatgrass has been much greater than in previous years.

fying biological invasions. Much better justification and certainly a better opportunity to contribute to the solution of a major societal problem could be achieved by distilling this information into spatially explicit case histories and predictions on the consequences of biological invasions for public review, discussion, and action. One pay-off would be the emergence of epidemiological models conceptually similar to those produced for human parasites, such as the avian influenza virus (Germann et al. 2006), which have proved so effective in prediction and public education.

One handicap to convincing the public and policy makers of the consequences of biological invasions is that, in comparison to the spread of human pathogens, most invasions can initially appear as slow-moving, localized, and even cryptic. The public is often reluctant to concede that an environmental crisis is looming. Alternatively, if the damage occurs in months or a few years, public response can be extremely swift. Such events have occurred through the actions of parasitic IAS, most notably the horrific loss of foundation tree species, such as the American chestnut, in the eastern part of the US in the first half of the 20th century, and the ongoing demise of the eastern hemlock and jarrah in the US and Australia, respectively (Ellison et al. 2005). Accurately portraying invasions in spatially explicit models would do much to raise public perception of the potential consequences of these phenomena.

\section{Where do we go from here?}

Assembling a neutral assessment of the spatial spread of non-native species - from those that are exterminated soon after arrival in a new range, to those that eventually 
come to cover $10^{6}$ ha and inflict much damage - would provide an invaluable public service. Much remains to be accomplished, however, if we are to provide this and other services.

- A much more concerted effort is needed to develop better data-collection tools and procedures.

- Global cooperation among biologists concerned with IAS should be facilitated, along with the exchange of relevant information. For example, web-accessible databases with unified formats are being assembled by an international collaborative effort of scientists and managers (www.gisinetwork.org); these ensure universal access. Unified datasets must be flexible and retain their integrity over time.

- Assembly of the massive amounts of data we envision is a potential prescription for obscuring the issues, unless emphasis is placed on data presentation in a readily available format, with clearly drawn conclusions, including answers to questions like "what if action is/is not taken?" - queries that policy decisions often hinge on.

- Development of collaborative efforts against IAS similar to those for human parasites, such as the US National Institutes of General Medical Services' Models of Infectious Disease Agent Study (www.nigms.nih.gov/ Initiatives/MIDAS), which constructs computational models of parasites, hosts (analogous to recipient ranges), and spread. Such networks build on the synergism from experimentalists, informatics groups, and field practitioners to combat pathogens effectively.

Our goal - aside from understanding the why and how of invasions at all spatial scales - is to provide the public with a rationale for studying these organisms, similar to the one that society readily accepts as justification for investigations in global public health. The World Health Organization (WHO; www.who.org) is empowered to study and combat human pathogens across the planet because invasive pathogens recognize no political or physical boundaries; neither do the other species that are now becoming invasive. And while the damage they cause may not lead to wholesale threats to human health (although some do), the resulting human misery and costs nonetheless justify that we investigate and, ultimately, combat them at the same multiple spatial scales on which the WHO now operates.

\section{Acknowledgements}

The authors thank the workshop participants for their valuable insights and contributions, J Carlton and L
Kinter for useful information and comments, and the organizers of the ESA Merida meeting, J Herrick and J Sarukhan, along with O Sala, for their support. BVH was supported by an American Association for the Advancement of Science (AAAS) Science and Engineering Fellowship at the United States Environmental Protection Agency (EPA). LAM was supported by the University of Rhode Island College of Environmental Life Sciences. The research described in this paper has been funded in part by the EPA through cooperative agreement number CR828392 with AAAS. The views expressed herein may not necessarily reflect the views of EPA or AAAS and no official endorsement should be inferred.

\section{References}

Drake JM and Lodge DM. 2004. Global hotspots of biological invasions: evaluating options for ballast-water management. P Roy Soc Lond B Bio 271: 575-80.

Ellison AM, Bank MS, Clinton BD, et al. 2005. Loss of foundation species: consequences for the structure and dynamics of forested ecosystems. Front Ecol Environ 3: 479-86.

Germann TC, Kadau K, Longini IM, and Macken CA. 2006. Mitigation strategies for pandemic influenza in the United States. P Natl Acad Sci USA 103: 5935-40.

$\rightarrow$ Lodge DM. 1993. Biological invasions: lessons for ecology. Trends Ecol Evol 8: 133-37.

Mack RN. 1996. Predicting the identity and fate of plant invaders: emergent and emerging approaches. Biol Conserv 78: 107-21.

Mack RN. 2005. Assessing biotic invasions in time and space: the second imperative. In: Mooney HA, Mack RN, McNeely JA, et al. (Eds). Invasive alien species: a new synthesis. Washington, DC: Island Press.

Meyerson LA , Carroll I, O'Malley R, et al. Tracking non-native species: indicator design and data assessment for the United States. Washington, DC: The Heinz Center. In press.

Parker IM, Simberloff D, Lonsdale WM, et al. 1999. Impact: towards a framework for understanding the ecological effects of invaders. Biol Invas 1: 3-19.

Petersen KS, Rasmussen KL, Heinemeier J, and Rud N. 1992 Calms before Columbus? Nature 359: 679.

Pimentel D, Zuniga R, and Morrison D. 2005. Update on the environmental and economic costs associated with alien-invasive species in the United States. Ecol Econ 52: 273-88.

Sax DF, Stachowicz JJ, and Gaines SD. 2005. Species invasions: insights into ecology, evolution, and biogeography. Sunderland, MA: Sinauer Associates.

Spencer, DF and Kasander, GG. 2005. Seasonal growth of water hyacinth in the Sacramento/San Joaquin Delta, California. J Aquat Plant Manage 43: 91-94.

With KA. 2002. The landscape ecology of invasive spread. Conserv Biol 16: 1192-1203.

${ }^{1}$ School of Biological Sciences, Washington State University, Pullman, WA $99164 *$ (rmack@mail.wsu.edu); ${ }^{2}$ Office of Research and Development, US Environmental Protection Agency, Washington, DC 20460; current address: Department of Biology, University of Central Florida, Orlando, FL 32816; 3 Department of Natural Resource Sciences, University of Rhode Island, Kingston, RI 02881 